\title{
Phylogenetic analysis of the family Beloceratidae (Ammonoidea; Late Devonian) and a new Beloceras species from eastern Iran
}

\author{
VACHIK HAIRAPETIAN \& DIETER KORN
}

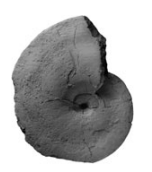

\begin{abstract}
The cladistic analysis of the beloceratid ammonoids Mesobeloceras and Beloceras shows anagenetic development, by increasing number of sutural elements, in the stem group representatives and cladogenesis in the crown group. Crown group topology rules out vicariant evolution of the beloceratids and does not show palaeogeographic patterns. The widespread occurrences of multilobate species of Beloceras suggests connected low-latitude shelf areas between the regions of the Anti-Atlas, Montagne Noire, Rhenish Mountains, Shotori Range, Altay, and Canning Basin. A new species of Beloceras, Beloceras sardarense sp. nov., is described. - Key words: Ammonoidea, Devonian, Iran, phylogeny, biogeography.
\end{abstract}

HAIRAPETIAN, V. \& KORN, D. 2011. Phylogenetic analysis of the family Beloceratidae (Ammonoidea; Late Devonian) and a new Beloceras species from eastern Iran. Bulletin of Geosciences 86(4), 675-682 (6 figures, 2 tables). Czech Geological Survey, Prague. ISSN 1214-1119. Manuscript received February 28, 2011; accepted in revised form April 20, 2011; published online June 15, 2011; issued November 16, 2011.

Vachik Hairapetian, Department of Geology, Khorasgan (Isfahan) Branch, Islamic Azad University, P.O. Box 81595-158, Isfahan, Iran; vachik@khuisf.ac.ir • Dieter Korn, Museum für Naturkunde Berlin, Invalidenstraße 43, D-10115 Berlin, Germany; dieter.korn@mfn-berlin.de

Beloceras is one of the most spectacular of the Palaeozoic ammonoids. It has the most multilobate suture line of all Devonian ammonoids; some of the species possessing up to 50 individual lobes and a conch shape that undergoes conspicuous ontogenetic changes (Korn et al. 2011). Beloceras is distributed in nearly all equatorial shelf areas of the middle and late Frasnian and regularly accompanies the genus Manticoceras.

The concept of species differentiation within the genus Beloceras has been discussed often during the last few decades (e.g. by Yatskov 1990, Korn \& Klug 2002, and Korn et al. 2011). Conservative approaches have used only a few species names for the material assembled in the various regions (e.g. Rhenish Mountains, Montagne Noire, Anti-Atlas, Altay, and the Canning Basin). All records within these regions were usually attributed to only two species, B. sagittarium (e.g. by Bogoslovsky 1958, 1969; Glenister 1958) or B. tenuistriatum (e.g. by Korn \& Klug 2002). Korn \& Klug (2002) synonymised most of the species and only treated B. tenuistriatum and B. stenumbilicatum as valid.

An alternative concept has been expressed by Yatskov (1990), who interpreted every single occurrence as a different species and introduced several new genera and subgenera within the family Beloceratidae. Yatskov (1990, p. 38) proposed a phylogram with independent evolutionary lineages, each ending with extremely multilobate species. This hypothesis was not popular with ammonoid researchers, probably because it differed too much, in its radical splitting concept, from the existing taxonomic and phylogenetic concepts of the family Beloceratidae.

In a recent account, Korn et al. (2011) revised material of Beloceras from the Rhenish Mountains and the Anti-Atlas and reached the conclusion that in fact endemic species do occur in these regions. They partly supported the taxonomic concept proposed by Yatskov (1990) but did not reach a conclusion on whether the phylogenetic relationships that he outlined were likely or not. After submission of the manuscript, the second author became aware of material of Beloceras from the Kale Sardar section in the Shotori Range (eastern Iran). This occurrence is already known within the literature (Clapp 1940; Wendt et al. 1997, 2005; Yazdi 1999; Gholamalian 2007) but has not yet been described. In the following paper, another new endemic species of Beloceras will be introduced from this locality.

\section{Geographic and stratigraphic setting}

A number of scattered hills, representing Late Devonian "cephalopod beds" of the Shishtu Formation, are widely exposed on the northern bank of the Sardar River, west of 
Kale Sardar (Hill IV)
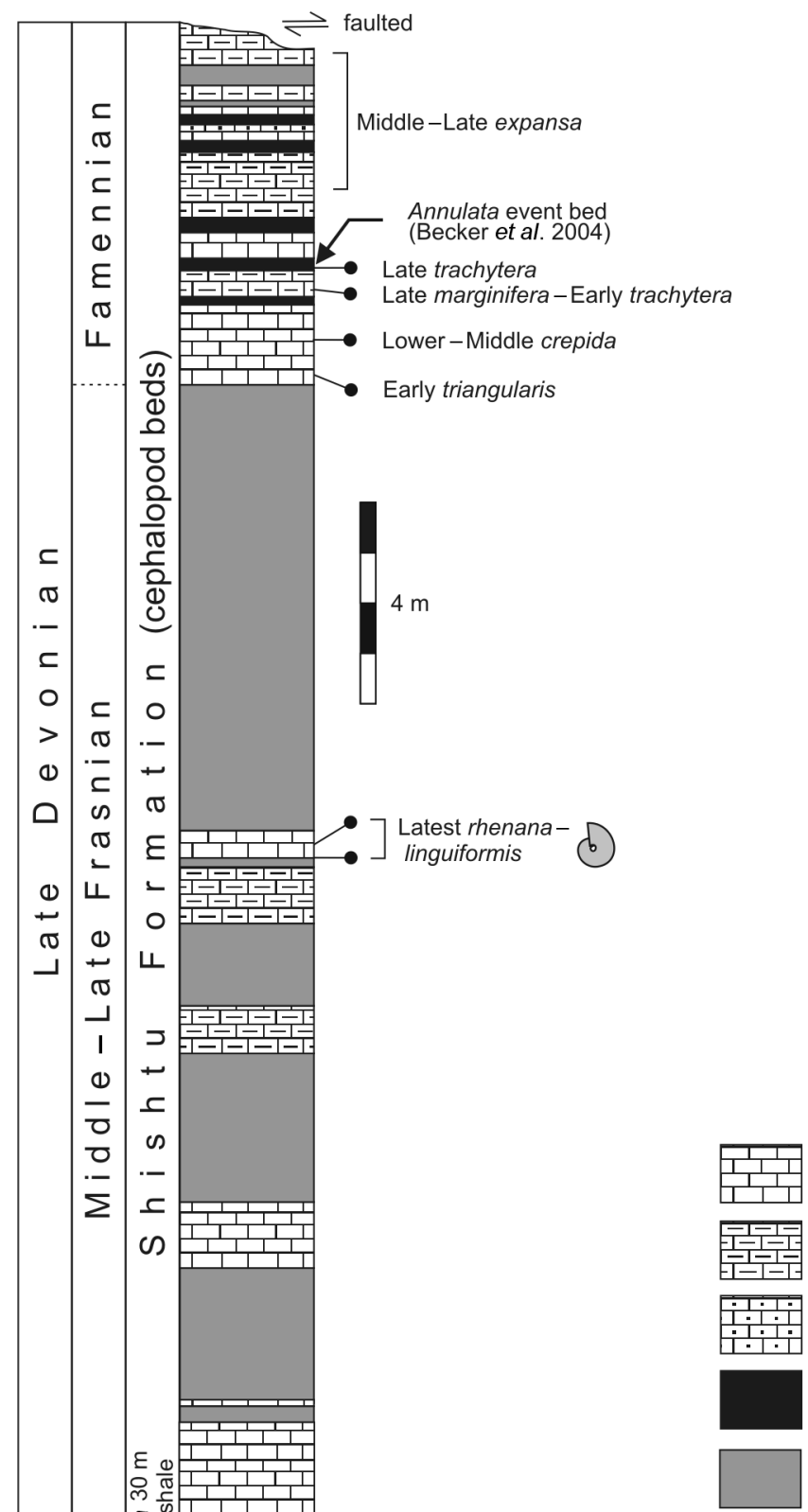

lime

limestone

marly limestone

sandy limestone

marl

shale
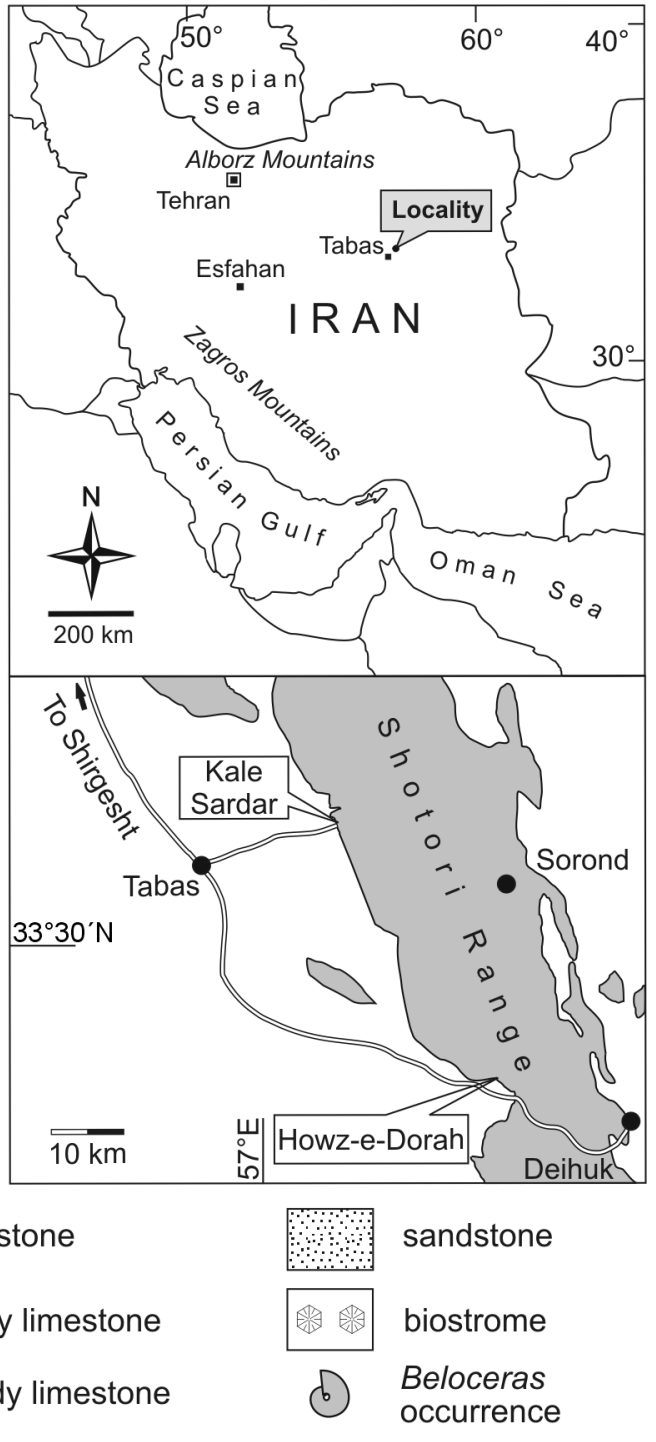

occurrence

Figure 1. Geographic position of the Kale Sardar locality in the Shotori Range (eastern Iran) and the stratigraphic succession of the Shishtu Formation with the position of the Beloceras bearing horizon.

the Shotori Range, eastern Iran. After an early report by Clapp (1940), the outcrops in Kale Sardar were first studied in detail by Stöcklin et al. (1965). Thus far, this fossiliferous section was the most interesting locality in eastern Iran and has been featured in several works (Flügel 1961; Sartenaer 1966; Walliser 1966; Haas \& Mensink 1970; Schultze 1973; Haas 1994; Legrand-Blain 1999; Yazdi 1999; Morzadec 2002; Feist et al. 2003; Becker et al. 2004; Ashouri 2002, 2004; Gholamalian 2007; Gholamalian et al. 2009; Webster et al. 2007; Hairapetian \& Ginter 2010).
The new specimens of Beloceras were collected from a section (Hill IV in Becker et al. 2004), located approxi-

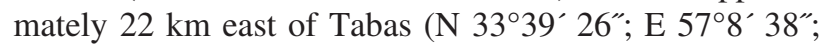
Fig. 1). The lithology of the section commences with a series of oolitic limestones alternating with green shale grading into a condensed set of marls, marly limestones, and shales. The oolitic limestone, which contains Beloceras specimens changes laterally to a coeval red ferruginous ammonoid-bearing bed, in which Manticoceras ammon was found by Walliser (1966). 
From the samples K5H and K5 in the oolitic limestone, very rich conodont assemblages including Icriodus alternatus alternatus, I. alternatus helmsi, I. alternatus mawsonae, Ancyrodella buckeyensis, Ancyrognathus triangularis, Palmatolepis gigas gigas, Pa. winchelli, Polygnathus aequalis, $P$. evidens, $P$. politus, $P$. procerus, $P$. webbi, and $P$. vachiki were collected (Gholamalian 2007, table 2). These species suggest an age interval from the Late rhenana to the linguiformis Zones (Gholamalian 2007) and this is entirely consistent with an earlier conodont dating (Yazdi 1999, p. 176).

\section{Systematic palaeontology}

Suborder Gephuroceratina Ruzhencev, 1957

Superfamily Belocerataceae Hyatt, 1884

Family Beloceratidae Hyatt, 1884

\section{Genus Beloceras Hyatt, 1884}

Type species. - Goniatites sagittarius Sandberger \& Sandberger, 1851, p. 77.

\section{Beloceras sardarense sp. nov.}

Figure 2

1999 Beloceras tenuistriatum - Yazdi, p. 171

2005 Beloceras tenuistriatum - Wendt et al., p. 56.

Derivation of name. - After the Sardar River, where the material was collected.

Holotype. - Specimen MB.C.21997 (Hairapetian Coll.); illustrated in Fig. 2.

Type locality and horizon. - Northern bank of the Sardar River, $22 \mathrm{~km}$ east of Tabas (Shotori Range, Central Iran); Shishtu Formation (late Frasnian).

Material. - The holotype and a poorly preserved paratype from the type locality.

Diagnosis. - Species of Beloceras with extremely discoi$\mathrm{dal}(\mathrm{ww} / \mathrm{dm}=0.24)$ and involute conch $(\mathrm{uw} / \mathrm{dm}=0.14 \mathrm{in}$ stages larger than $70 \mathrm{~mm} \mathrm{dm}$ ). Umbilical wall rather steep; shallow spiral groove in the midflank area. Suture line with six secondary prongs of the external lobe, a very narrow V-shaped lateral lobe, and eight umbilical lobes on the

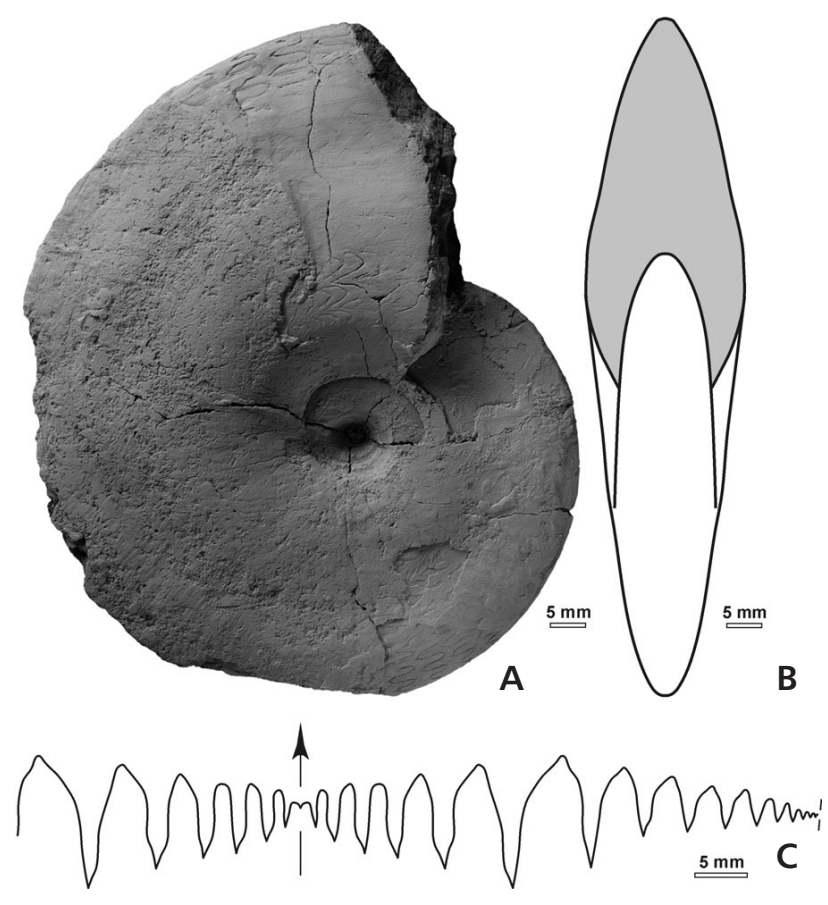

Figure 2. Beloceras sardarense sp. nov., holotype MB.C.21997 from Kale Sardar (Hairapetian Coll.). $\bullet$ A - lateral view; $\times 0.7$. B - dorsal view; $\times 0.7$. $\bullet \mathrm{C}$ - suture line at $96.1 \mathrm{~mm} \mathrm{dm}, 22.5 \mathrm{~mm}$ ww, $49.5 \mathrm{~mm}$ wh; $\times 1.0$.

flanks at a conch diameter of $95 \mathrm{~mm}$; formula of the ventral suture line in this growth stage $\left(\mathrm{E}_{2} \mathrm{E}_{3} \mathrm{E}_{4} \mathrm{E}_{5} \mathrm{E}_{6} \mathrm{E}_{7} \mathrm{E}_{1} \mathrm{E}_{7} \mathrm{E}_{6}\right.$ $\left.\mathrm{E}_{5} \mathrm{E}_{4} \mathrm{E}_{3} \mathrm{E}_{2}\right) \mathrm{L} \mathrm{U}_{2} \mathrm{U}_{4} \mathrm{U}_{6} \mathrm{U}_{8} \mathrm{U}_{10} \mathrm{U}_{12} \mathrm{U}_{14} \mathrm{U}_{16} \mathrm{U}_{18}$ ). Prongs of the external lobe are narrowly $\mathrm{V}$-shaped to lanceolate; the saddles between the $\mathrm{U}_{8}$ lobe and the $\mathrm{E}_{4}$ lobe are tectiform.

Description. - Holotype MB.C.21997 is a fully septate specimen with a conch diameter measuring $97 \mathrm{~mm}$ (Fig. 2A, Table 1). It is extremely discoidal $(\mathrm{ww} / \mathrm{dm}=$ 0.24 ) and involute ( $\mathrm{uw} / \mathrm{dm}=0.14$ ) with a narrowly rounded venter and an oblique, slightly incurved umbilical wall. The flanks converge towards the venter and possess a shallow midflank groove, which is very weak at the beginning of the last preserved whorl but becomes more prominent towards the end of the phragmocone (Fig. 2A, B).

The suture line of the holotype was drawn at a conch diameter of $96 \mathrm{~mm}$ (Fig. 2C). It shows six secondary prongs of the external lobe, all being very narrow and deep. These lobes differ in their outline; the $\mathrm{E}_{2}$ lobe is $\mathrm{Y}$-shaped with a very narrow base and converging flanks in the upper half, the $\mathrm{E}_{3}$ lobe is lanceolate with slightly pouched flanks, the $\mathrm{E}_{4}$ and $\mathrm{E}_{5}$ lobes are asymmetric with slightly curved ventral flanks, and the $\mathrm{E}_{6}$ lobe is small and narrowly V-shaped. The L lobe is Y-shaped with a very narrow base and flanks

Table 1. Conch dimensions (in $\mathrm{mm}$ ) and proportions for the holotype of Beloceras sardarense sp. nov. from Kale Sardar.

\begin{tabular}{ccccccccccccc}
\hline & $\mathrm{dm}$ & ww & wh & uw & ah & ww/dm & ww/wh & uw/dm & WER & IZR \\
\hline MB.C.21997 & 97.0 & 23.0 & 51.3 & 13.7 & 35,8 & 0.24 & 0.45 & 0.14 & 2.51 & 0.30 \\
\hline
\end{tabular}




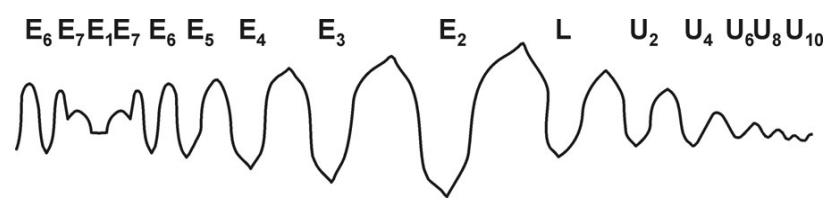

Figure 3. Suture line terminology used in this paper.

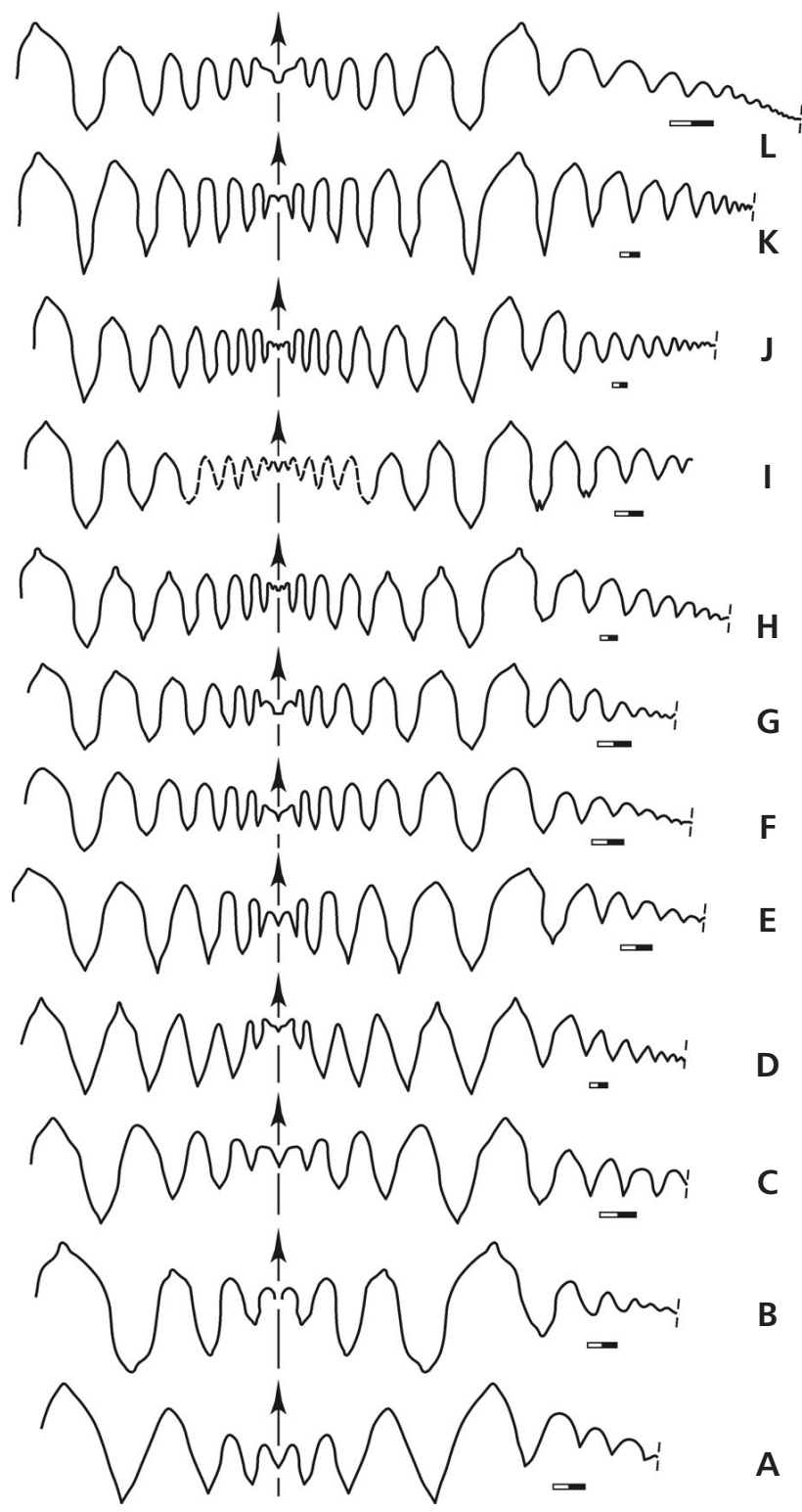

Figure 4. Suture lines of the beloceratid species included in the phylogenetic analysis. • A - Mesobeloceras kayseri (Holzapfel, 1882), specimen MB.C.22067 from the Beul in the Rhenish Mountains (Denckmann Coll.), at $11.1 \mathrm{~mm} w w, 28.6 \mathrm{~mm}$ wh. • B - Mesobeloceras thomasi Glenister, 1958, holotype after Glenister (1958, fig. 12b), at $35 \mathrm{~mm} \mathrm{dm}$. - C - Beloceras webbelense Korn et al., 2011, paratype MB.C.22026 (Paeckelmann 1920 Coll.) from the Martenberg near Adorf (Rhenish Mountains), at $8.4 \mathrm{~mm}$ ww, $23.6 \mathrm{~mm}$ wh (after Korn et al. 2011). - D - Beloceras petterae Yatskov, 1990, specimen MB.C.22033.1 (Bockwinkel Coll.) from Hassi Nebech (Anti-Atlas, Morocco), at $13.2 \mathrm{~mm}$ ww, ca $50 \mathrm{~mm}$ wh (after Korn et al. 2011). • E - Beloceras diverging strongly in the uppermost part. The umbilical lobes are rather uniform in their outline, being V-shaped and becoming smaller towards the umbilicus. Seven of the saddles in the midflank area (between the $\mathrm{U}_{8}$ lobe and the $\mathrm{E}_{4}$ lobe) are tectiform at their top, with the saddle between the $\mathrm{L}$ and $\mathrm{E}_{2}$ lobes being dominant and slightly mammiform.

Comparisons. - The new species cannot be confused with any of the other Beloceras species. It differs from all of the other known species of the genus in the presence of the midflank spiral groove, producing a slender pear-shaped whorl cross section. Furthermore, B. sardarense has a stouter conch than all of the other species (ww/dm $=0.24$ in $B$. sardarense and less than 0.20 in the other species).

Species such as B. sagittarium and B. sardarense are similar in number and shape of their sutural elements, but in B. sardarense, seven saddles show a tectiform outline (only three or four saddles do this in the other species of the genus). Furthermore, the lobes (particularly the $\mathrm{L}$ and $\mathrm{E}_{2}$ lobes) are narrower and deeper in $B$. sardarense.

\section{Phylogenetic analysis of Beloceras species}

Cladistic analyses of ammonoids have only rarely been done (for a summary, see Neige et al. 2007, Yacobucci in press). However, in some case studies (e.g. Landman 1989; Korn 1997, 2001; Monks 1999; Moyne \& Neige 2004; McGowan \& Smith 2007) it has been proven that the method can be successfully applied to this fossil group.

We analysed the beloceratid ammonoids (genera Mesobeloceras and Beloceras; Figs 3, 4) using the parsimonious cladistic method (Figs 5, 6) using the PAST software (Hammer et al. 2008), and the following preconditions formed its framework:

- Twelve taxa were included: two species of Mesobeloceras and ten species of Beloceras.

jorfense Korn et al., 2011, holotype MB.C.22047 (Wendt Coll.) from Tantana (Anti-Atlas, Morocco), at $61.1 \mathrm{~mm} \mathrm{dm}, 10.7 \mathrm{~mm}$ ww, $30.0 \mathrm{~mm}$ wh (after Korn et al. 2011). F - Beloceras tenuistriatum (d'Archiac \& de Verneuil, 1842), specimen MB.C.22007 (Denckmann 1893 Coll.) from the Martenberg near Adorf, at $37.0 \mathrm{~mm} \mathrm{dm}, 9.0 \mathrm{~mm} w w, 19.0 \mathrm{~mm}$ wh (after Korn et al. 2011). • G - Beloceras bogoslovskyi (Yatskov, 1990), paratype after Bogoslovsky (1969, fig. 102zh), at $28.7 \mathrm{~mm}$ wh. - H - Beloceras glenisteri (Yatskov, 1990), holotype after Glenister (1958, fig. 14), at $126 \mathrm{~mm} \mathrm{dm}$. - I - Beloceras schulzi (House \& Kirchgasser, 1985), holotype after House \& Kirchgasser (in House et al. 1985, fig.10a). - J - Beloceras sagittarium (Sandberger \& Sandberger, 1851), specimen MB.C.19183 (Schultz 1967 Coll.) from the Braunsberg near Tegau (Thuringian Mountains), at $128.5 \mathrm{~mm} \mathrm{dm}, 26.5 \mathrm{~mm}$ ww, $67.5 \mathrm{~mm}$ wh (after Korn et al. 2011). $\bullet \mathrm{K}$ - Beloceras sardarense sp. nov., holotype MB.C.21997 from Kale Sardar (Hairapetian Coll.), at $96.1 \mathrm{~mm}$ $\mathrm{dm}, 22.5 \mathrm{~mm}$ ww, $49.5 \mathrm{~mm}$ wh. $\cdot \mathrm{L}$ - Beloceras stenumbilicatum Bogoslovsky, 1958, holotype after Bogoslovsky (1969, fig. 102z), at $20.7 \mathrm{~mm}$ wh. Scale bar $=2 \mathrm{~mm}$. 

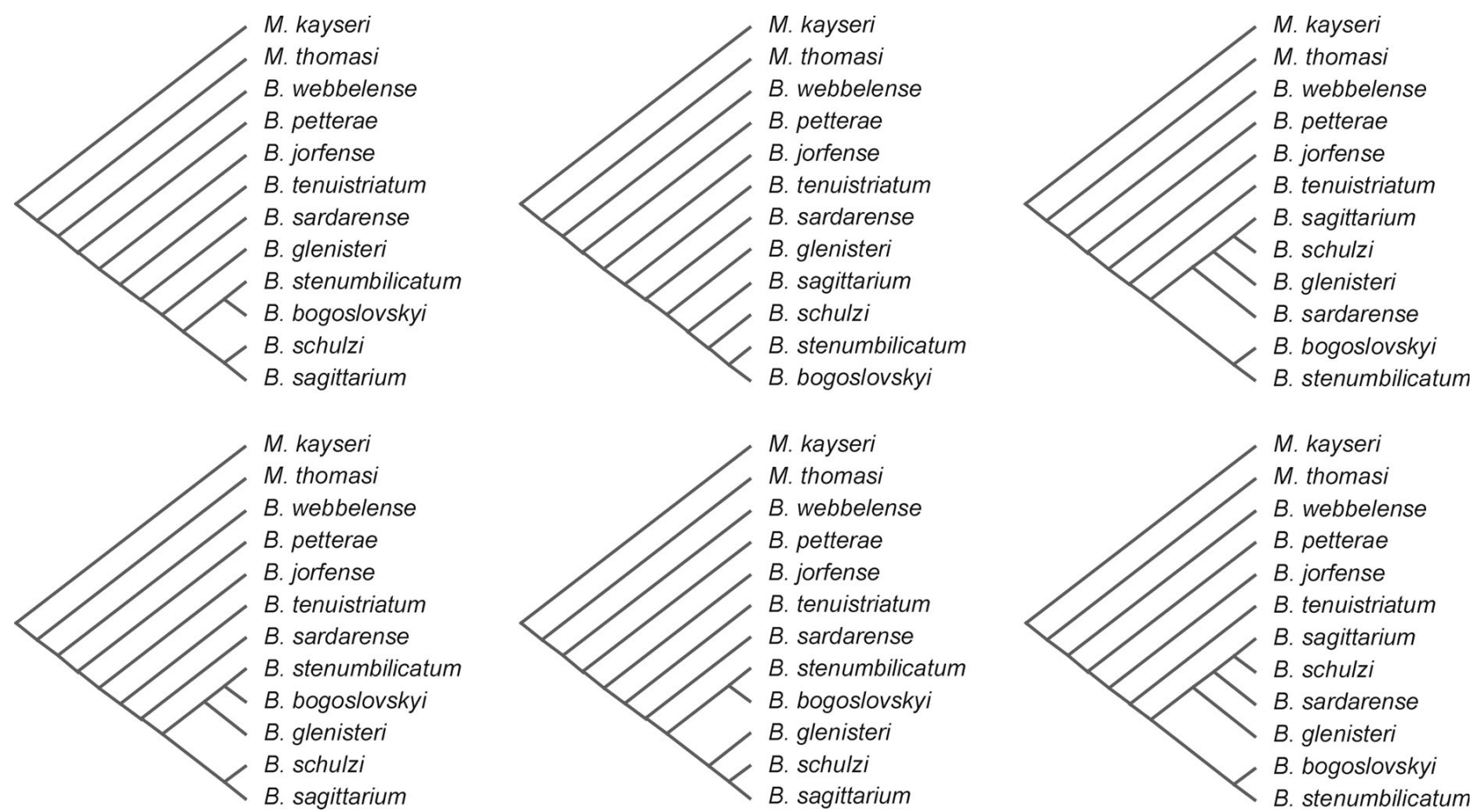

Figure 5. Phylogenetic analysis of the beloceratid ammonoids, six most parsimonious trees.
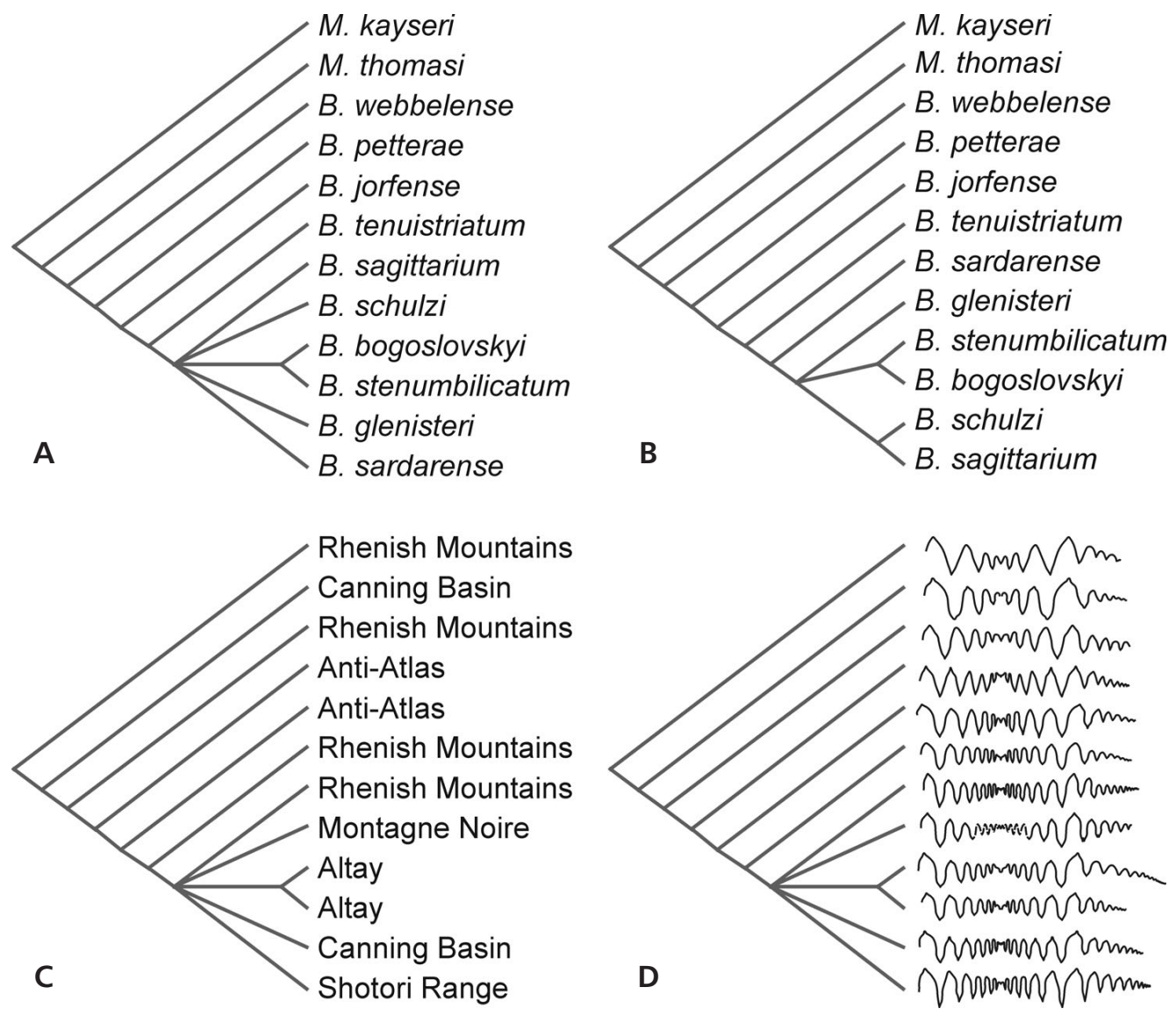

Figure 6. Phylogenetic analysis of the beloceratid ammonoids. $\bullet \mathrm{A}-$ strict consensus tree. $\bullet \mathrm{B}-50 \%$ majority consensus tree. $\bullet \mathrm{C}-$ strict consensus tree with the regions with the beloceratid species. $\bullet \mathrm{D}-$ strict consensus tree with the suture lines of the beloceratid species. 
Table 2. Character list used in the analysis of the beloceratid species.

\begin{tabular}{|c|c|c|c|c|c|}
\hline No. & Character & Character state 0 & Character state 1 & Informative & $\mathrm{CI}$ in $\mathrm{mp}$ trees \\
\hline 1 & uw/dm ratio & $>0.25$ & $<0.25$ & yes & 1.00 \\
\hline 2 & uw/dm ratio & $>0.20$ & $<0.20$ & yes & 1.00 \\
\hline 3 & uw/dm ratio & $>0.15$ & $<0.15$ & yes & 0.50 \\
\hline 4 & umbilical rim & strong & moderate or weak & yes & 1.00 \\
\hline 5 & umbilical rim & strong or moderate & weak & yes & 0.25 \\
\hline 6 & lateral groove & no & yes & no & 1.00 \\
\hline 7 & ventrolateral groove & no & yes & yes & 0.50 \\
\hline 8 & E lobe prongs & $<3$ & $>3$ & yes & 1.00 \\
\hline 9 & E lobe prongs & $<4$ & $>4$ & yes & 1.00 \\
\hline 10 & E lobe prongs & $<5$ & $>5$ & yes & 1.00 \\
\hline 11 & U lobes & $<3$ & $>3$ & yes & 1.00 \\
\hline 12 & U lobes & $<4$ & $>4$ & yes & 1.00 \\
\hline 13 & U lobes & $<5$ & $>5$ & yes & 0.33 \\
\hline 14 & E4 lobe width & moderate & narrow & yes & 0.50 \\
\hline 15 & E4 lobe shape & V-shaped & lanceolate & yes & 1.00 \\
\hline 16 & E4-E3 saddle & rounded & not rounded & yes & 1.00 \\
\hline 17 & E4-E3 saddle & not acute & acute & yes & 0.50 \\
\hline 18 & E4-E3 saddle & not tectiform & tectiform & yes & 1.00 \\
\hline 19 & E3 lobe width & moderate & narrow & yes & 0.26 \\
\hline 20 & E3 lobe shape & V-shaped & lanceolate & yes & 1.00 \\
\hline 21 & E3-E2 saddle & acute & tectiform & yes & 0.50 \\
\hline 22 & E2 lobe width & moderate & narrow & yes & 0.33 \\
\hline 23 & E2 lobe width & narrow & very narrow & no & 1.00 \\
\hline 24 & E2 lobe shape & V-shaped & lanceolate & yes & 0.50 \\
\hline 25 & E2-L saddle & acute & tectiform & yes & 1.00 \\
\hline 26 & L lobe width & moderate & narrow & yes & 0.67 \\
\hline 27 & L lobe width & narrow & very narrow & no & 1.00 \\
\hline 28 & L lobe shape & V-shaped & lanceolate & yes & 0.44 \\
\hline 29 & L lobe subdivided & no & yes & no & 1.00 \\
\hline 30 & L-U2 saddle & rounded & tectiform & yes & 0.33 \\
\hline 31 & U2 lobe width & wide & moderate or narrow & yes & 1.00 \\
\hline 32 & U2 lobe width & wide or moderate & narrow & yes & 0.53 \\
\hline 33 & U2 lobe shape & V-shaped & lanceolate & yes & 0.32 \\
\hline 34 & U2 lobe subdivided & no & yes & no & 1.00 \\
\hline
\end{tabular}

- Mesobeloceras kayseri (Holzapfel, 1882) was chosen as the outgroup because it has the lowest number of sutural elements out of all of the analysed species.

- A total of 34 characters were included, all with the two character states 0 and 1 . Therefore, some quantitative characters (e.g. the number of sutural elements) with more than two character states were split into singular characters.

- Seven characters refer to the conch shape and 27 characters to the suture line.

The analysis revealed the following results:

- Of the 34 characters, 29 of them are informative (Ta- ble 2) and 5 are autapomorhic characters (regarding only the species Beloceras sardarense and B. schulzi).

- The parsimony analysis led to six most parsimonious trees with a tree length of 57 steps.

- Differences between these six trees regard only the crown group (composed of the six most multilobate species).

- The consensus trees show two patterns, (1) anagenesis in the stem group representatives (Mesobeloceras and less multilobate species of Beloceras) and (2) cladogenesis in the crown group (multilobate species of Beloceras). 
- The strict consensus tree (Fig. 6A) shows the crown group with five branches rooting in one node; these five branches represent the five regions (Montagne Noire, Rhenish Mountains, Altay, Shotori Range, Canning Basin) from which the six multilobate species of Beloceras (B. sagittarium, B. schulzi, B. bogoslovskyi, B. stenumbilicatum, B. sardarense, B. glenisteri) are known (Fig. 6C).

- The 50\% majority tree (Fig. 6B) shows B. sardarense (Shotori Range) as the sister group of three separate branches, (1) B. sagittarium and B. schulzi (Rhenish Mountains, Montagne Noire), (2) B. bogoslovskyi and B. stenumbilicatum (Altay), and (3) B. glenisteri (Canning Basin).

- The consistency index of the analysis is 0.60.

- Of the 29 informative characters, 14 of them have a consistency index of 1 within the six most parsimonious trees.

- The consistency index of the informative characters in the six most parsimonious trees is 0.71 .

- There is no visible general pattern in the quality of the characters. The consistency index of the characters referring to distinct sutural elements (width, shape) does not prove any of the characters to be of any particular value.

- Characters that are very stable are those that refer to the number of sutural elements (secondary prongs of the external lobe, umbilical lobes).

\section{Results and discussion}

The phylogenetic analysis of the beloceratid ammonoids allows for a number of interpretations:

1. The genus Beloceras is monophyletic. - The cladograms show that the distribution of characters rules out a polyphyletic origin of the genus (Figs 5, 6).

2. There are major trends in the phylogeny of the beloceratid ammonoids. - This result is not surprising because the tendency towards multilobate suture lines, as seen in the beloceratids, is also known from a number of Palaeozoic and Mesozoic ammonoid lineages, e.g. late Middle Devonian pharciceratids (Bogoslovsky 1969), Early Carboniferous acrocanitids (Korn et al. 2007), Carboniferous and Permian medlicottiids (Ruzhencev 1949), and Triassic pinacoceratids (Mojsisovics 1873). In these cases there occurs a covariation with the transformation of conch geometry; the multilobate taxa are also the ones with a narrow umbilicus.

3. There are no parallel lineages within Beloceras leading to multilobate species, as proposed by Yatskov (1990, p. 38). All multilobate species of the genus are rooted in a common node, and the multiplication of prongs of the external lobe as well as the umbilical lobe can be regarded as a synapomorphic character (Fig. 6D).

4. The cladograms can be interpreted in a way that suggests that there is no vicariance in the evolution of the beloceratid ammonoids. Species of different complexity within distinct regions (Rhenish Mountains, Anti-Atlas, Canning Basin) do not form monophyla, ruling out independent vicariant evolutionary lineages (Fig. 6C).

5. The cladograms do not allow the recognition of palaeogeographic patterns. In the species constituting the crown group (the multilobate species of Beloceras), all geographic regions are separate branches rooting in one node. The only exceptions may be the Rhenish Mountains and the Montagne Noire, which in five of the six most parsimonious trees form a monophyletic unit. However, this result may be caused by the incomplete data set for B. schulzi (question marks in characters 10 and 13) and its overall similarity to $B$. sagittarium.

6. The phylogenetic analysis of the beloceratid ammonoids suggests a correspondence of the faunas between the equatorial shelves (regions Anti-Atlas, Montagne Noire, Rhenish Mountains, Shotori Range, Altay, and the Canning Basin). In light of this result, the middle and late Frasnian can be seen as a time interval of pronounced cosmopolitism.

\section{Acknowledgements}

We are indebted to Sonny A. Walton (Potsdam) for checking the manuscript and Volker Ebbighausen (Odenthal) as well as Jürgen Bockwinkel (Leverkusen) for their reviews of the paper.

\section{References}

Archiac, V. D' \& Verneuil, M.E. DE 1842. On the Fossils of the Older Deposits in the Rhenish Provinces; preceded by a general Survey of the Fauna of the Palaeozoic Rocks, and followed by a Tabular List of the Organic Remains of the Devonian. Transactions of the Geological Society of London (2)6, 303-410. DOI 10.1144/transgslb.6.2.303

Ashouri, A.R. 2002. Palmatolepis (Conodonta, Late Devonian) from the Tabas region, Eastern Iran. Iranian International Journal of Science 3, 187-220.

Ashouri, A.R. 2004. Late Devonian and Middle-Late Devonian conodonts from eastern and northern Iran. Revista Española de Micropaleontologia 3, 355-365.

Becker, R.T., Ashouri, A.R. \& YAZDI, M. 2004. The Upper Devonian Annulata Event in the Shotori Range (eastern Iran). Neues Jahrbuch für Geologie und Paläontologie, Abhandlungen 231, 119-143.

Bogoslovsky, B.I. 1958. Devonskie ammonoidei Rudnogo Altaya. Trudy Paleontologicheskogo Instituta Akademiya Nauk SSSR 64, 1-155.

Bogoslovsky, B.I. 1969. Devonskie ammonoidei. I. Agoniatity. Trudy Paleontologicheskogo Instituta Akademiya Nauk SSSR 124, 1-341.

Clapp, F.G. 1940. Geology of eastern Iran. Bulletin of the Geological Society of America 51, 1-102. 
Feist, R., Yazdi, M. \& Becker, T. 2003. Famennian trilobites from the Shotori Range, E-Iran. Annales de la Société géologique du Nord 10 (2 $2^{\text {ème }}$ série), 285-295.

FlüGEL, H.W. 1961. Receptaculites neptuni Defr. 1827 from the Upper Devonian Kuh-i-Shotori, east Iran. Bulletin of the Iranian Petroleum Institute 4, 75-81.

Gholamalian, H. 2007. Conodont biostratigraphy of the Frasnian-Famennian boundary in the Esfahan and Tabas areas, Central Iran. Geological Quarterly 51, 453-476.

Gholamalian, H., Ghorbani, M. \& Sajadi, S.-H. 2009. Famennian conodonts from Kal-e-Sardar section, Eastern Tabas, Central Iran. Rivista Italiana di Paleontologia e Stratigrafia $115,141-158$.

Glenister, B.F. 1958. Upper Devonian ammonoids from the Manticoceras Zone, Fitzroy Basin, Western Australia. Journal of Paleontology 32, 50-96.

HaAs, W. 1994. Eine neue Asteropyginae-Art mit vier Seitenstacheln und die Bedeutung der Zufallszahlen in der Morphogenese des Pygidiums der Trilobiten. Courier Forschungsinstitut Senckenberg 169, 225-238.

HaAs, W. \& Mensink, H. 1970. Asteropyginae aus Afghanistan (Trilobita). Akademie der Wissenschaften und der Literatur, Mainz, Mathematisch-Naturwissenschaftlichen Klasse, Abhandlungen 1969, 155-211.

Hairapetian, V. \& Ginter, M. 2010. Pelagic chondrichthyan microremains from the Upper Devonian of Kale Sardar section, eastern Iran. Acta Geologica Polonica 60, 357-371.

Hammer, O., Harper, D.A.T. \& Ryan, P.D. 2008. PAST Palaeontological Statistics, ver. 1.77. http://folk.uio.no/ohammer/past/past.pdf

Holzapfel, E. 1882. Die Goniatitenkalke von Adorf in Waldeck. Palaeontographica, Neue Folge 8, 225-261.

House, M.R., Kirchgasser, W.T., Price, J.D. \& Wade, G. 1985. Goniatites from Frasnian (Upper Devonian) and adjacent strata of the Montagne Noire. Hercynica 1, 1-19.

Hyatt, A. 1883-1884. Genera of fossil cephalopods. Proceedings of the Boston Society of Natural History, 253-338.

Korn, D. 1997. Evolution of the Goniatitaceae and ViséanNamurian biogeography. Acta Palaeontologica Polonica 42(2), 177-199.

KoRn, D. 2001. Morphometric evolution and phylogeny of Palaeozoic Ammonoids. Early and Middle Devonian. Acta Geologica Polonica 51(3), 193-215.

Korn, D., Bockwinkel, J., Ebbighausen, V. \& Walton, S.A. 2011. Beloceras, the most multilobate Late Devonian ammonoid. Bulletin of Geosciences 86(1), 1-20. DOI 10.3140/bull.geosci.1247

Korn, D. \& KLug, C. 2002. Ammoneae Devonicae. Fossilium Catalogus. I. Animalia 138.375 pp. Backhuys Publishers, Leiden.

LANDMAN, N.H. 1989. Iterative progenesis in Upper Cretaceous ammonites. Paleobiology 15, 95-117.

Legrand-Blain, M. 1999. A Frasnian productid brachiopod fauna from Kale Sardar, Tabas region, eastern Iran. Société Géologique du Nord, Annales 7 (2 ème série), 13-19.

McGowan, A.J. \& Smith, A.B. 2007. Ammonoids across the Permian-Triassic boundary: A cladistic perspective. Paleobiology 50, 573-590.

Mojsisovics, E. von MoJsvár 1873. Das Gebirge um Hallstatt. Eine geologisch-paläontologische Studie aus den Alpen. I.
Theil. Die Mollusken-Faunen der Zlambach- und HallstätterSchichten. Abhandlungen der kaiserlichen und königlichen geologischen Reichsanstalt 6(1), I-VII, 1-174.

MonKs, N. 1999. Functional morphology, ecology, and evolution of the Scaphitidae Gill, 1871 (Cephalopoda). Journal of Molluscan Studies 66, 205-216. DOI 10.1093/mollus/66.2.205

Morzadec, P. 2002. Trilobites Asteropyginae dévoniens d'Iran. Geobios 35, 411-427. DOI 10.1016/S0016-6995(02)00037-2

Moyne, S. \& Neige, P. 2004. Cladistic analysis of the Middle Jurassic ammonite radiation. Geological Magazine 141, 115-223. DOI 10.1017/S0016756804009082

Neige, P., Rouget, I. \& Moyne, S. 2007. Phylogenetic practices among scholars of fossil cephalopods, with special reference to cladistics, 3-14. In LANDMAN, N.H., DAvis, R.A. \& MAPES, R.H. (eds) Cephalopods Present and Past: New Insights and Fresh Perspectives. Springer, New York.

RuZHENCEv, V.E. 1949. Sistematika i evolyutsia semeystv Pronoritidae Frech i Medlicottiidae Karpinsky. Trudy Paleontologicheskogo Instituta Akademiya Nauk SSSR 19, 1-206.

RuZHENCEv, V.E. 1957. Filogeneticheskaya sistema paleozoiskikh ammonoidei. Byulleten' Moskovskogo Obshchestva Ispytateley Prirody, Otdel Geologicheskiy 32(2), 49-64.

SAndBerger, G. \& SANDBerger, F. 1850-1856. Die Versteinerungen des rheinischen Schichtensystems in Nassau. Mit einer kurzgefassten Geognosie dieses Gebietes und mit steter Berücksichtigung analoger Schichten anderer Länder. I-XIV, 564 pp., 41 pl. Kreidel \& Niedner, Wiesbaden.

SARTENAER, P. 1966. Frasnian Rhynchonellida from the OzbakKuh and Tabas regions (East Iran). Geological Survey of Iran, Report 6, 25-53.

Schultze, H.-P. 1973. Large Upper Devonian arthrodires from Iran. Fieldiana Geology 23, 53-78.

Stöcklin, J., Eftekhar-NeZhad, J. \& Hushmand-Zadeh, A. 1965. Geology of the Shotori Range (Tabas area, east Iran). Geological Survey of Iran, Reports 3, 1-69.

WALLISER, O.H. 1966. Preliminary notes on Devonian, Lower and Upper Carboniferous goniatites in Iran. Geological Survey of Iran, Reports 6, 7-24.

Webster, G.D., Maples, C.G. \& YAzdi, M. 2007. Late Devonian and Early Mississippian echinoderms from central and northern Iran. Journal of Paleontology 81, 1101-1113. DOI 10.1666/pleo05-151.1

Wendt, J., Hayer, J. \& Karimi Bavandpour, A. 1997. Stratigraphy and depositional environment of Devonian sediments in northeast and east-central Iran. Neues Jahrbuch für Geologie und Paläontologie, Abhandlungen 206, 277-322.

Wendt, J., Kaufmann, B., Belka, Z., Farsan, N. \& Karimi BavandPuR, A. 2005. Devonian/Lower Carboniferous stratigraphy, facies patterns and palaeogeography of Iran. Part II. Northern and central Iran. Acta Geologica Polonica 55, 31-97.

YACOBUCCI, M.M. In press. Meta-analysis of character utility and phylogenetic information content in cladistic studies of ammonoids. Geobios.

YAтsKov, S.V. 1990. K sistematike semeystva Beloceratidae (Ammonoidea). Trudy Paleontologicheskogo Instituta Akademiya Nauk SSSR 243, 36-51.

YAZDI, M. 1999. Late Devonian-Carboniferous conodonts from eastern Iran. Rivista Italiana di Paleontologia e Stratigrafia 105, 167-200. 